\title{
Customer's repurchase intensions following service recovery: A conceptual model
}

\author{
Muhammad Mazhar ${ }^{1,}$, and Ting Ding Hooi ${ }^{2}$ \\ 1,2 Department of Management and Humanities, Universiti Teknologi PETRONAS, 32610 Malaysia
}

\begin{abstract}
An effective strategy of service recovery that prevents customer defection after service failure is a powerful managerial instrument. The values that a customer associates and considers with repurchasing after service recovery has changed due to globalization. Although service recovery has been identified as a key driver to retain the customers, yet the effectiveness of service recovery is unclear. The literature did not offer a comprehensive service recovery strategy that can be implemented universally. Owing to varying comments on the effectiveness of service recovery, its generalizability is questionable. Grudge produced in the response of service failure that cannot be compensated with financial transactions. This study will check whether service recovery has any impact on customer's repurchase intentions when customer has grudges and available substitutes. The findings of this research will help the managers and practitioners to allocate their resources in a proper way. Furthermore, this study will help to understand money or extrinsic compensation is not everything. Therefore, there will be some consideration beyond the materialist compensation. It will open up new avenues for researchers to view service recovery strategies with a different angle.
\end{abstract}

\section{Introduction}

Extensive debates have been going on among researchers regarding service recovery without any clear consensus on the matter. Service recovery is considered as a key factor in retaining customers. However, the effectiveness of service recovery is still a matter of debate. Establishment of an effective service recovery strategy is considered a challenging task across the world. Researchers presume that service recovery has a positive impact on customer satisfaction (Du et al., 2010), future repurchase intention (Komunda \& Osarenkhoe, 2012) and positive word of mouth (Osarenkhoe \& Komunda, 2013). It is also suggested it has immense potential to overcome initial dissatisfaction and enhance relationship (McCollough et al., 2000). Some researchers have concluded that even excellent service recovery is not enough to restore attitude and behavior of customer.

\footnotetext{
* Corresponding author: muhammad_18001815@utp.edu.my
} 
"Alternative attractiveness" and "Grudge-Holding" are considered as the two main reasons hindering the formation of a consensus among researchers on the matter of effectiveness of service recovery. Firstly, a person who receives a loss due to service failure feels that he has experienced an intrinsic harm and it is deemed by the customer as a breach of trust which is more consternating than the physical loss. Secondly competitive services/products also have an impact on the future intentions of customer. After encountering service failure, a customer complains to the service provider and receives service recovery. However, he may also choose another similar product. This may also cause a change in the customer behavior. This shows that service recovery does not always necessarily ensure customer retention. A customer forms his judgement and choice through his experiences and observations. The increasing intensity of competition in recent years, among companies means that the companies cannot depend on stereotype marketing tools endlessly if they wish to expand their market shares globally. They need to have specific personalized marketing programs and strategies to capture each group of consumers around the world that have behavioral and consumption patterns in order to win these selected target market (Sian et al., 2010).

Most of the researchers tend to focus only on a single point-of-time period. However, that single point of time period could be biased and incapable to provide a complete picture of the event. For instance, when a customer experiences service failure how should a company act to reduce customer dissatisfaction. The researchers suggest that this can be done by providing service recovery in the form of financial compensation, customers can be retained (Migacz et al., 2017). But it is completely overlooked whether those customers who received service recovery are purchasing again from the same company or not (a complete picture of the event). In reality, companies keep losing their customers even after providing them with service recovery. A complete service recovery process is not available that can be used by practitioners to minimize the customer's service avoidance and switching

\section{Literature Review}

\subsection{Service recovery and repurchase intentions}

Businesses try to maximise their profits by retaining happy customers. A defensive strategy to keep the existing customer is less expensive as compared to attracting new customers through an offensive strategy. Attracting new customers is five times more expensive than keeping an existing ones (Alshurideh, 2016). It has been observed that if a company re-acquires $5 \%$ of its angry customers that will boost profit from $25 \%$ to $95 \%$ (Jacob, 1994). A high level of interactions is involved among service providers and their users. When customers build a relationship with a service provider then they expect better from the seller. If customer expectations are not met by a seller then the chance of service failure is increased. Several authors have considered that this high level of relationship increases the customers' expectations as well as the chance of a service failure (Chueh et al., 2014; Komunda \& Osarenkhoe, 2012). Good service performance is essential to customer satisfaction. (Wallin Andreassen, 2000) conclude that customers' negative reaction is common feature of service failure. Furthermore, this reaction further influences satisfaction evaluation of service recovery and future willingness to repurchase from the same seller.

Service failures are inevitable because of the integral inconsistency of service performance (Zeithaml et al., 1990). When a customer receives a service which is below his 
expectations, it makes the customer feel negatively about the service experience, a service failure has happened (Gelbrich \& Roschk, 2011). If service providers do not deal with service failures properly, it can drive customers to produce negative WOM, and may result in decreased profits (Bitner et al., 2000; Tronvoll, 2011). The service failure and poorly handled complaints are certainly not forgotten and these customers are vulnerable to defection (Rotte et al., 2006).

Service failure is an alarming issue faced by companies frequently. To avoid the loss of customers, companies take corrective action termed as service recovery. However, the question is: should they see service recovery as context specific or generic? Extensive evidence exists to suggest that good service recovery has a positive effect on the customer satisfaction ( Du et al., 2010), future intentions to repurchase (Komunda \& Osarenkhoe, 2012) and positive word of mouth (Osarenkhoe \& Komunda, 2013). It is also suggested that sometimes it overcome initial dissatisfaction and enhance relationship (McCollough et al., 2000). On the other hand, (Andreassen, 2001; Lee \& Zahn, 2014; Zeithaml et al., 2006) provide contradictory evidence which suggests that even excellent recovery may not ensure restoration of customers' attitude and behavioral intentions. Cultural, societal, situational and personal factors can impact the behaviors and actions of customers. Therefore, it could be safe to say that service recovery is context specific.

Even the best service providing companies are unable to provide error free services every time. Therefore, planning for the service recovery is the most important step to obtain a competitive edge (Xu et al., 2018). Subsequent recovery initiatives give a chance to service firm to repair relationship with customers (Beverland et al., 2009). In order to devise a successful recovery process, an organization must keep in consideration the perceptions and expectations of a customer after experiencing service failure and recovery. Service providers engage themselves in problem solving activities to counteract service failure and to minimize service or product defections (Maxham III \& Netemeyer, 2002; Nguyen et al., 2012) with the hopes of transforming negative attitude of customer (Kuo et al., 2013). Collectively these measures are referred to as service recovery that are taken to restore the confidence and trust of angry consumers following a service failure experience (McCollough et al., 2000). For gaining trust and satisfaction of customers, companies provide financial benefits to its customers which include discounts, vouchers, cash back and replacement etc. To earn maximum profits by retaining happy customers. It is less expensive for an organization to adopt defensive strategy and keep existing customers than to undertake an offensive strategy to attract new customers. Attracting new customers is five times more expensive than keeping exiting customer (Alshurideh, 2016).

There is a growing body of knowledge that compensation is considered as a high rated strategy for service recovery. Recent evidence suggests that monetary compensation has a greater effect on customer satisfaction, loyalty, trust, repurchase intensions. However, some researchers favour non-monetary compensation like apology and explanation as a better strategy to satisfy customers. The recovery paradox is also dependent on the context and situation. Factors beyond the control of companies can influence service recovery and make it impossible for the companies to change the attitude of dissatisfied customers (Zeithaml et al., 2006). There is a continuous discussions and debates regarding the extent to which the service recovery paradox exists. There are different opinions on the issue. Both (Zeithaml et al., 2006) as well as (Michel \& Meuter, 2008) argue that, even though they believe that the service recovery paradox exists, in the long run the best strategy is to "doing it right the first time" (Zeithaml et al., 2006). Despite theoretical and empirical support to service recovery as a key driver of repurchases intentions and behavior but there is evidence (Andreassen, 2001; Lee \& Zahn, 2014; Zeithaml et al., 2006) suggest that service recovery may have no impact on repurchase intention under specific circumstances. 


\subsection{Alternative product and repurchase Intention}

In a highly competitive service environment, it becomes a tough ask for organizations to reacquire their dis-satisfied customers by developing an effective strategy for providing service recovery to retain their customers (Migacz et al., 2017). In a competitive environment customer have more power to select best alternative product/service. So, in this situation it is very difficult for the companies to survive in the industry. The intense competition in the market has driven the companies to place to pay extra attention to service recovery so as to ensure sustainable success. In an ever-expanding retailing industry, retailers (one of the major beneficiaries) are driven to reconsider their business strategies to achieve higher customer loyalty. Previous studies show that interest in service recovery has increased because service failure experience often leads to customer switching (Li et al., 2019). It is very harmful for a company to lose its customers owing to poor delivery services. An excellent service recovery after a service failure encounter is important for marketers (Zhou et al., 2013). In today's competitive world customers have more demanding attitudes and inflated expectations. Such customers pose a challenge to retailers in terms of service recovery (Martin et al., 2018). Substitute products reduce or even eliminate the positive impact of service recovery.

Customers' expectations about the performance of product/service are based on different service promises like price, tangibles and intangibles and it varies from customer to customer (Zeithaml et al., 1993). Furthermore, quality of interactions with employees, physical environment of the store and quality of the product/service also have a significant impact on the expectations of customers (Cronin Jr et al., 2000). For example, customers of business class of an airline have more expectation than the customers who are travelling in economy class (Liu et al., 2013). Though both customers are travelling through the same airline, but expectations are different. Similarly, expectations of customers for service recovery varies from customer to customer. If the expectations of a customer are much higher than the actual services received, negative emotions will be generated which leads to product/service switching and negative WOM.

Available competitive products play an important role in customer repurchase especially when he has encountered service failure. Alternative product attractiveness refers to customer's perception about availability of alternative choices in market, is an important indicators of customer's switching (Liu et al., 2016). In a competitive retail market customers have multiple choices. When customers encountered with service failure, they perceive the key attributes of alternative products which are better than the original, users are likely to switch. Though, service provider offers service recovery to customers against service failure, but customers do not repurchase from the same company. Hence, we posit that alternative attractiveness has negative effect on customer's repurchase intention.

$\mathrm{P}_{1}$ : Alternative product weakens the relationship between service recovery and repurchase intention.

\subsection{Grudge and Repurchase Intention}

Service failure affects the customer emotions negatively. These negative emotions sometimes turn into an extreme situation which is called grudge. Grudge holding has been defined in a marketing context as customers' extreme exit or tendency to exit and never come back (Huefner \& Hunt, 1992; Hunt et al., 1988). Service failure experience potentially leads to endless grudges that may be expensive for the company (Aron et al., 2007). Holding a grudge is not simply customer's dissatisfaction from the services or anger against a company whereas it is reaction of customers due to the emotions evoked by the experience of dissatisfaction (Walsh et al., 2019). In the state of grudge holding, the 
relationship between customer and service provider has been changed in the form of reduced revenue and retaliatory activities (Walsh et al., 2019). In the study of (GORDON, 2006) he found that the time duration of holding a grudge that a customer can hold during his life, he argued that an individual can hold the grudge against a company more than thirty years.

The customers, who are collectivist in nature, prefer to complaint within their social circle (family, friends and community members) rather than to the company. The customer believe that it is better to share their bad experience of service within their social network than complaint to service provider. Grudge-holding is a psychological process and it may be linked with customer's marketing behaviors, such as exit from the relationship, lack of commitment, complaining to company or third party, and negative word-of-mouth (Aron, 2001). Furthermore, consequences of service failure led the customers to loss of trust. Customers show their direct consequences in shape of complaining and retaliation whereas avoidance is an indirect consequence of grudge. From these arguments it can be assume that grudge-holding would have an important cause of customers and service provider relationship.

It is not necessary in all contexts that the service recovery give same results. Grudge holding is an important factor in studying consumer behavioral intentions. Grudge is a psychological process in which customer maintain a victim role and perpetuate negative emotions associated with rehearsing some hurtful offense (Bunker \& Ball, 2008). It may be link with customers' marketing behavior like exit from the relationship, lack of commitment, complaining and word-of-mouth (Walsh et al., 2019). The avoidance behavior more directly the consequence of grudge-holding (Bunker \& Ball, 2008). Literature shows that service recovery strategies either financial or non-financial have positive impact and it increase the satisfaction, loyalty, positive WOM and repurchase intentions. But we propose that in a specific group of customers (Collectivist) service recovery do not play any role and customer do not repurchase from the same seller even after getting service recovery. Hence, we hypothesized that service recovery may or may not have impact customer's repurchase intentions. If service recovery will have any impact on customer satisfaction, then they will accept the companies offer and repurchase from the same seller otherwise they will avoid and switch the seller.

$\mathrm{P}_{2}$ : Grudge-hold has significant negative effect on repurchase intention

\subsection{Conceptual framework}

The authors propose that two broad that can moderate the relationship between service recovery and repurchase intentions. Service recovery may have no impact on customers repurchase intention in the presence of grudge and choice. Proposed relationship showed in figure below. 


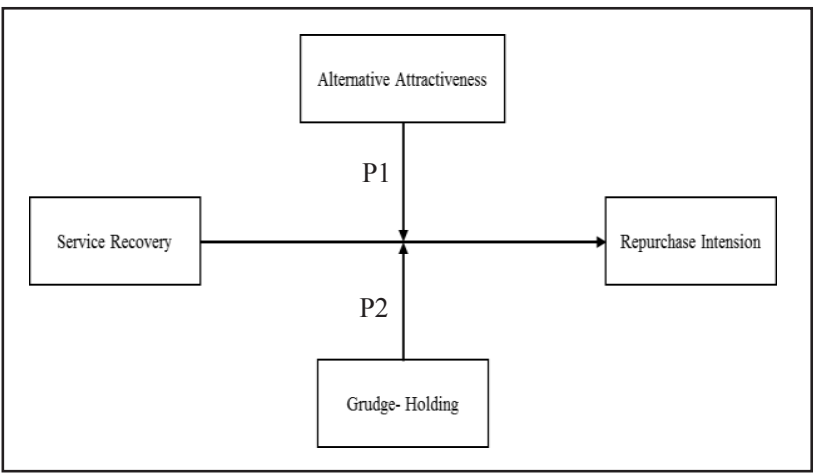

The illustration above demonstrates the relationship between service recovery and repurchase intention. This relationship is directly proportionate to each other. However, factors such as "alternative attractiveness" and "grudge-holding" negatively impact this relationship. When a customer holds a grudge or has an alternative which he can switch to even good service recovery cannot ensure repurchase intention and an organization is likely to loose its customers due to its poor service recovery.

\section{Conclusion and Discussion}

Current research proposed the outcome of alternative products and grudge holding on repurchase intention after getting service recovery. The negative side of service recovery has been over-sighted so far. According to the previous researchers, service recovery has the power to retain the angry customers after service failure, evidences exist to propose that good service recovery has a positive effect on the customers' satisfaction (Du et al., 2010), future intentions for repurchasing (Komunda \& Osarenkhoe, 2012) and positive word of mouth (Osarenkhoe \& Komunda, 2013) However, there are many factors that can stop the customers to repurchase from the same seller after taking service recovery. If customer has alternative products available in market or hold grudge against poor services of seller it will leads him/her to switching. Furthermore, current study has contributed to the existing body of knowledge by exploring the other side of service recovery. However, service recovery has positive effect on repurchase intention but in some circumstances, customers do not repurchase from the same seller. Current research will be helpful for the managers and practitioners to improve their service recovery strategies by focusing on the available alternative products and cope up the grudges of customer. By this way companies can retain their customers and reduce the customer switching behavior. Current research will also be helpful to consider such kind of customer who hold grudge for a long time how can they retain them. This research will be helpful for future researcher to implement and test the proposed model.

\section{References}

Alshurideh, M. T. J. J. o. R. i. M. (2016). Is customer retention beneficial for customers: A conceptual background. 5(3), 382-389.

Andreassen, T. W. (2001). From disgust to delight: do customers hold a grudge? Journal of Service Research, 4(1), 39-49. 
Aron, D. (2001). Consumer grudgeholding: Toward a conceptual model and research agenda. Journal of Consumer Satisfaction, Dissatisfaction and Complaining Behavior, 14, 108.

Aron, D., Judson, K., Aurand, T., \& Gordon, G. (2007). Consumer Grudgeholding: Does Age Make a Difference? American Journal of Business, 22(1), 45-58. https://doi.org/10.1108/19355181200700004

Beverland, M. B., Chung, E., \& Kates, S. M. (2009). Exploring consumers' conflict styles: grudges and forgiveness following marketer failure. ACR North American Advances.

Bitner, M. J., Brown, S. W., \& Meuter, M. L. (2000). Technology infusion in service encounters. Journal of the Academy of Marketing Science, 28(1), 138-149.

Bunker, M. P., \& Ball, D. (2008). Causes and consequences of grudge-holding in service relationships. Journal of Services Marketing, 22(1), 37-47. https://doi.org/10.1108/08876040810851941

Chueh, T. Y., Wang, J. H., \& Liao, H. H. (2014). Effects of Service Recovery on Customer Satisfaction and Relationship Retention in Catering Industry. Anthropologist, 17(3), 857-863. <Go to ISI>://WOS:000340016100018

Cronin Jr, J. J., Brady, M. K., \& Hult, G. T. M. (2000). Assessing the effects of quality, value, and customer satisfaction on consumer behavioral intentions in service environments. Journal of retailing, 76(2), 193-218.

Du, J., Fan, X., \& Feng, T. (2010). An experimental investigation of the role of face in service failure and recovery encounters. Journal of Consumer Marketing, 27(7), 584-593.

Gelbrich, K., \& Roschk, H. (2011). A meta-analysis of organizational complaint handling and customer responses. Journal of Service Research, 14(1), 24-43.

GORDON, G. (2006). Consumer grudgeholding: An ounce of prevention is worth a pound of cure.

Huefner, J. C., \& Hunt, H. K. (1992). Brand and store avoidance: the behavioral expression of dissatisfaction. Journal of Consumer Satisfaction, Dissatisfaction and Complaining Behavior, 5, 228-232.

Hunt, H. K., Hunt, H. D., \& Hunt, T. C. (1988). Consumer grudge holding. Journal of Consumer Satisfaction, Dissatisfaction and Complaining Behavior, 1(1).

Komunda, M., \& Osarenkhoe, A. (2012). Remedy or cure for service failure? Effects of service recovery on customer satisfaction and loyalty. Business Process Management Journal, 18(1), 82-103.

Kuo, N. T., Chang, K. C., Cheng, Y. S., \& Lai, C. H. (2013). How Service Quality Affects Customer Loyalty in the Travel Agency: The Effects of Customer Satisfaction, Service Recovery, and Perceived Value. Asia Pacific Journal of Tourism Research, 18(7), 803-822. https://doi.org/10.1080/10941665.2012.708352

Lee, J., \& Zahn, W. (2014). Customer Evaluations of Service Recovery as a Function of Loyalty and Negative Emotion: A Conceptual Approach. Asia-Pacific Journal of Business \& Commerce, 6(2), 43-56.

Li, C.-J., Li, F., Fan, P., \& Chen, K. J. I. J. o. H. M. (2019). Voicing out or switching away? A psychological climate perspective on customers' intentional responses to service failure. 102361.

Liu, S. W., Law, R., Rong, J., Li, G., \& Hall, J. (2013). Analyzing changes in hotel customers' expectations by trip mode. International Journal of Hospitality Management, 34, 359-371. https://doi.org/10.1016/i.ijhm.2012.11.011 
Liu, Y., Li, H. X., Xu, X. Y., Kostakos, V., \& Heikkila, J. (2016). Modeling consumer switching behavior in social network games by exploring consumer cognitive dissonance and change experience. Industrial Management \& Data Systems, 116(4), 801-820. https://doi.org/10.1108/Imds-05-2015-0170

Martin, B., Strong, C., \& O'Connor, P. (2018). How psychologically entitled shoppers respond to service recovery apologies. European Journal of Marketing, 52(9-10), 2173-2190. https://doi.org/10.1108/Ejm-02-2017-0165

Maxham III, J. G., \& Netemeyer, R. G. (2002). A longitudinal study of complaining customers' evaluations of multiple service failures and recovery efforts. Journal of marketing, 66(4), 57-71.

McCollough, M. A., Berry, L. L., \& Yadav, M. S. (2000). An empirical investigation of customer satisfaction after service failure and recovery. Journal of Service Research, 3(2), 121-137.

Michel, S., \& Meuter, M. L. (2008). The service recovery paradox: true but overrated? International Journal of Service Industry Management, 19(4), 441-457.

Migacz, S. J., Zou, S., \& Petrick, J. F. (2017). The "Terminal" Effects of Service Failure on Airlines: Examining Service Recovery with Justice Theory. Journal of Travel Research, 57(1), 83-98. https://doi.org/10.1177/0047287516684979

Nguyen, D. T., McColl-Kennedy, J. R., \& Dagger, T. S. (2012). Matching service recovery solutions to customer recovery preferences. European Journal of Marketing, 46(9), 1171-1194. https://doi.org/10.1108/03090561211247865

Osarenkhoe, A., \& Komunda, M. B. (2013). Redress for customer dissatisfaction and its impact on customer satisfaction and customer loyalty. Journal of Marketing Development and Competitiveness, $7(2), 102-114$.

Rotte, K., Chandrashekaran, M., Tax, S. S., \& Grewal, R. d. (2006). Forgiven But Not Forgotten: Covert Uncertainty in Overt Responses and the Paradox of DefectionDespite-Trust. Journal of Consumer Psychology, 16(3), 283-294. https://doi.org/10.1207/s15327663jcp1603 10

Sian, F., Chuan, S., Kai, B., \& Chen, B. (2010). Culture and consumer behaviour: Comparisons between Malays and Chinese in Malaysia. International Journal of Innovation, Management and Technology, 1(2), 180.

Tronvoll, B. (2011). Negative emotions and their effect on customer complaint behaviour. Journal of Service Management, 22(1), 111-134. https://doi.org/10.1108/09564231111106947

Wallin Andreassen, T. (2000). Antecedents to satisfaction with service recovery. European Journal of Marketing, 34(1/2), 156-175. https://doi.org/10.1108/03090560010306269

Walsh, G., Deseniss, A., Ivens, S., \& Schaarschmidt, M. J. K. (2019). Buffering the service failure-induced effect of anger on revenge.

Xu, X., Liu, W., \& Gursoy, D. (2018). The Impacts of Service Failure and Recovery Efforts on Airline Customers' Emotions and Satisfaction. Journal of Travel Research, 58(6), 1034-1051. https://doi.org/10.1177/0047287518789285

Zeithaml, V. A., Berry, L. L., \& Parasuraman, A. (1993). The nature and determinants of customer expectations of service. Journal of the Academy of Marketing Science, 21(1), 1-12.

Zeithaml, V. A., Bitner, M. J., Gremler, D. D., \& Pandit, A. (2006). Services marketing: Integrating customer focus across the firm. 
Zeithaml, V. A., Parasuraman, A., Berry, L. L., \& Berry, L. L. (1990). Delivering quality service: Balancing customer perceptions and expectations. Simon and Schuster.

Zhou, Y. Y., Huang, M. X., Tsang, A. S. L., \& Zhou, N. (2013). Recovery strategy for group service failures The interaction effects between recovery modes and recovery dimensions. European Journal of Marketing, 47(8), 1133-1156. https://doi.org/10.1108/03090561311324255 